Pamiętnik Literacki 2021, 2, s. 249-263

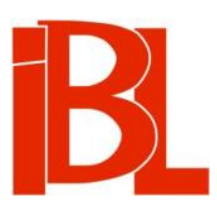

\title{
Literacki wizerunek Barbary z Bielińskich Kossowskiej
}

Krystyna Maksimowicz 


\section{LITERACKI WIZERUNEK BARBARY Z BIELIŃSKICH KOSSOWSKIEJ}

Barbara z Bielińskich Kossowska (1760-1801) nie wzbudza takiego zainteresowania badaczy czasów stanisławowskich jak wiele innych pań epoki, które zyskały rozgłos z różnych powodów, nawet jako „bohaterki” ścigających je błahych opowieści i plotek. Zwykle pojawiała się w kontekście swego męża, gdy próbowano kompromitować go jako przysłowiowego „rogacza”, albo jako dama brylujacca na salonach, olśniewająca urodą i wdziękiem. Niezwykłemu jej urokowi poddał się twórca często przywoływanego wiersza Do Kossowskiej w tańcu, który, co prawda, interesuje badaczy, jednakże głównie ze względu na atrybucję autorską. Ogólnie rzecz biorac, stworzono dwa wizerunki Kossowskiej: pierwszy jako damy komplementowanej i drugi - kobiety doznającej despektu. Tak ukształtowany konterfekt „bohaterki” wymaga jednak dopełnienia, o co postaram się w niniejszym studium.

Barbara Kossowska pochodziła $z$ rodu o wysokim prestiżu społecznym. Była córką marszałkówny wielkiej Wielkiego Księstwa Litewskiego Krystyny Justyny z Sanguszków, a wnuczką słynnej księżnej Barbary z Duninów Sanguszkowej, małżonki księcia Pawła Karola. Mirem cieszyła się także jej rodzina po mieczu. Ojciec, Franciszek Bieliński, syn wojewody chełmińskiego, Michała, sprawował liczne urzędy (konsyliarz Rady Nieustającej, pisarz wielki koronny), angażował się w działalność publiczną i prowadził interesy majątkowe. W pamięć Henriety z Działyńskich Błędowskiej zapadł jego wizerunek jako człowieka o szerokich horyzontach umysłowych, który „dużo jeździł za granice, rozmaite zbiory miał u siebie starożytności i kolekcje mineralogiczne, różne także mozaiki i malowidła” oraz bogatą bibliotekę ${ }^{1}$. Był gruntowanie wykształcony. Wspierając prace Komisji Edukacji Narodowej, postulował m.in. program nauczania kobiet, uwzględniający „naukę języków obcych, francuskiego i niemieckiego, a nadto geografii, historii, fizyki, logiki, retoryki i etyki" 2 .

Młoda Barbara wychowywała się w domu doceniającym naukę, o co szczególną troskę wykazali nie tylko rodzice, ale też opiekująca się nią - po śmierci jej matki -

1 H. z Działyńskich Błędows ka, Pamiątka przeszłości. Wspomnienia z lat 1794-1832. Oprac., wstęp K. Kostenicz, Z. Makowiecka. Warszawa 1960, s. 73.

2 I. Tu row s ka - B a r ow a, Bieliński Franciszek. Hasło w: Polski słownik biograficzny. T. 2. Kraków 1936, s. 50. Autorka podała, że ogłoszone drukiem listy F. Bi elińs ki e go pt. Sposób edukacji $w$ XV listach opisany, które do Komisji Edukacji Narodowej od bezimiennego autora były przesłane (1775) znalazły odzwierciedlenie w programach Komisji, która „przyjeła projekt Bielińskiego w sprawie nadzoru nad prywatnym wychowaniem kobiet oraz nauczaniem języka niemieckiego”. 
księżna Sanguszkowa. Ona to zapewniła wnuczkom - Barbarze oraz jej siostrom, Joannie i Tekli - odpowiednią dla młodych arystokratek edukację. Jak przebiegał proces nauczania dziewczynek powierzonych mentorce, pannie Gietulewiczównie, pisał Feliks Franciszek Łubieński, zięć księżnej Sanguszkowej, pełniący urząd ministra sprawiedliwości w czasach Księstwa Warszawskiego. Można uznać, że stosowane przez guwernantkę metody nauczania były dość zaskakujące, jako że „nie wykładała uczennicom żadnego przedmiotu, lecz zadawała tylko $\mathrm{z}$ francuskich książek pewne ustępy gramatyki, historii i geografii. Panienki obowiązane były wyuczyć się na pamięć i powtarzać dosłownie”. Zgodnie z duchem epoki, guwernantka kładła nacisk na naukę języków obcych. Rozmowy z dziewczynkami prowadziła wyłącznie po francusku lub po niemiecku. Poza znajomościa języków Barbara oraz jej siostry zdobyły umiejętność gry na klawikordzie, pięknie tańczyły i uczestniczyły w życiu towarzyskim organizowanym przez babkę w Warszawie, w podwarszawskim Szymanowie i w Poddębicach koło Sieradza. W tej ostatniej rezydencji „powtarzały się co wieczór wesołe tany”3.

Nie ulega wątpliwości, że dobro wnuków leżało księżnej na sercu, co uwidaczniało się w różnych sytuacjach, np. gdy z okazji zawarcia małżeństwa przez Teklę Bielińska (6 XI 1782) Sanguszkowa - jak przekazał Teodor Ostrowski - „dawała kawe $\mathrm{z}$ tańcami dla znaczniejszych w [...] stolicy osób, błogosławiąc wnukom i wnuczkom swoim, których ośmiu znajdowało się, licząc razem księcia Stanisława Jabłonowskiego, kasztelanica krakowskiego", a najznakomitszym świadkiem tego wydarzenia był Stanisław August Poniatowski ${ }^{4}$.

Obecność króla uświetniła także uroczystość zaślubin Barbary Bielińskiej z Rochem Kossowskim. W „Gazecie Warszawskiej” z 19 VII 1783 (na pierwszej stronie pisma) donoszono:

W przeszłą niedzielę [13 VII - K. M.] o godzinie 4 wieczorem w Pałacu J. P. Bielińskiego, starosty czerkieskiego, dawał ślub J. Ks. Okęcki, biskup poznański i warszawski [...]. Nastapiła potem wspaniała kolacja, na której Najjaśniejszy Pan z licznym gronem państwa i ministrów znajdował się ${ }^{5}$.

Z pewnością mariaż wnuczki księżnej Sanguszkowej zasługiwał na aplauz ze strony rymujących, a tymczasem - co jest faktem zdumiewającym - nie ma chociażby jednego epitalamium na cześć nowożeńców, mimo iż zwykle „bohaterom” o tej randze społecznej towarzyszyły okolicznościowe (panegiryczne) utwory. Powiemy więcej: że milczenie poetów - a nie brakowało ich przecież w otoczeniu chociażby samej księżnej Sanguszkowej - w tak ważnej sprawie jak ślub można uznać za symptomatyczne. Czyżby sceptycyzm związany z doborem małżonków wpłynął na brak rymowanych ślubnych powinszowań? Ponad 20-letnia różnica wieku między Barbarą a Rochem mogła wyzwalać nieufność co do szczęśliwego pożycia i trwałości związku. Jeśli dodamy do tego niezwykłą urodę panny młodej i mało atrakcyjny wygląd małżonka, to wątpliwości związane z mariażem oparte były na realnych przesłankach.

3 Pamiętniki Feliksa hr. Łubieńskiego, ministra sprawiedliwości. Skreślił i oprac. W. C h o m ę t o ws ki. Warszawa 1876, s. 44, 52-53, 69, 93-94. Zob. A. J a k u b o s z c z a k, Sarmacka dama. Barbara Sanguszkowa (1718-1791) i jej salon towarzyski. Poznań 2008, s. 100.

4 T. Os trow s ki, Poufne wieści z oświeconej Warszawy. Gazetki pisane z roku 1782. Oprac., wstęp R. Kale ta. Wrocław 1972, s. 194: „Z Warszawy, die 21 novembris 1782”.

5 „Gazeta Warszawska” 1783, nr 58, z 19 VII (sobota). 
Ostrym piórem (co nie oznacza, że nieobiektywnym) wygląd Kossowskiego opisał Leon Dembowski. Powiązany rodzinnie i zawodowo z Czartoryskimi autor wspominał m.in. swój pobyt w Puławach, gdzie widywał Rocha Kossowskiego, aczkolwiek należy zaznaczyć, że przedstawiony wizerunek dotyczy człowieka starego i schorowanego. Dembowski wspominał: „W chwili, gdy go tam poznałem, był to prawdziwy automat: niski, łysy, z ogromnym cienkim harcapem, uszy miał niepospolitej długości. Ręce sparaliżowane, zawsze milczący, jadł tylko i pił, w Puławach po kilka tygodni siedział”. Odwołując się zaś do opinii innych osób, Dembowski ujawniał: „Słyszałem, że dom jego w Bełżycach słynął z gościnności i uprzejmości”, co uznał za pozytywną cechę Kossowskiego, gdyż konkurowanie w tym zakresie z domami „Czartoryskich w Puławach, Lubomirskich w Opolu, Sanguszków w Lubartowie" nie było łatwe ${ }^{6}$.

Gdy Kossowski łączył się węzłem małżeńskim z Barbarą Bielińską, od trzech lat był wdowcem. Jego pierwsza żona, Konstancja z Łubieńskich, zmarła w 1780 roku. W pamięci współczesnych zapisała się dobrze. Zawarta w korespondencji Grzegorza Piramowicza wiadomość o jej śmierci ukazuje ją w jak najlepszym świetle:

Dowiaduję się bardzo smutny o śmierci podskarbiny Kossowskiej. Nie mogę wyrazić, jak mię niezmiernym żalem przeraża ta strata kobiety tak życzliwej jak dla mnie i [od] wszystkich powszechnie szanowanej, której przyjaźń dla mnie była mi jedną z najszacowniejszych ${ }^{7}$.

Ogólnie dobrą opinią cieszył się także Roch Kossowski, od 1762 r. podskarbi nadworny koronny, a od 1992 r. podskarbi wielki koronny. W czasie Sejmu Wielkiego stał na czele powołanej przez ten organ Komisji Skarbu. Jego wypowiedzi na temat Skarbu przyniosły mu powszechny szacunek. W krążącej w latach osiemdziesiątych XVIII w. satyrycznie ujętej Definicji wszystkich ministrów polskich $w$ czterech wierszach Kossowski wypadł dobrze; określono go słowem „Cnota”, co w zestawieniu $\mathrm{z}$ „etykietami” innych ministrów (np. podskarbiowie: Wędzikiszka, Hołota, Szubienicznik) wygląda wręcz doskonale ${ }^{8}$. Chwalono jego powściagliwość w kwestiach finansowych w związku z podniesieniem podskarbiostwa nadwornego do rzędu ministerstw, co znalazło wyraz m.in. w twórczości literackiej. Sprawę uposażenia Kossowskiego zwykle łączono z powszechnym szacunkiem, jakim go darzono: „Najmniej płatny z ministrów, choć więcej pracuje / Niż wszyscy razem, ale go naród szacuje" (w. 101-102) ${ }^{9}$. Opinię tę potwierdzali zarówno jemu współ-

6 L. Dembowski, Moje wspomnienia. T. 1. Petersburg 1898, s. 83-84. Zob. T. Korzon, Wewnętrzne dzieje Polski za Stanisława Augusta (1764-1794). Badania historyczne ze stanowiska ekonomicznego i administracyjnego. Wyd. 2. T. 4. Kraków 1897, s. 236. - B. Kr a kow s ki, Kossowski Roch. Hasło w: Polski słownik biograficzny, t. 14 (Wrocław 1968-1969).

7 G. Pi r a m o w i c z, list do I. Potockiego, z Genewy, d. 17 Julii 1780. Archiwum Publiczne Potockich, rkps 279 B, t. 1, s. 224. O złym stanie zdrowia pierwszej żony Rocha Kossowskiego, Konstancji z Łubieńskich, donoszono w gazetkach pisanych od początku 1780 r. („krwawienie z piersi”), a po śmierci nie szczędzono jej pochwał. Podkreślano jej wielkie talenty, urodę i ukazywano ją jako przykładną żonę, kochaną przez męża.

8 Zob. Sensacje z dawnych lat. Wyszukał i skomentował R. Ka le ta. Wyd. 2, udoskonalone i poszerz. Wrocław 1980, s. 24.

9 J. I. Ko s sakowski [?], Żądania próżne. W zb.: Wiersze polityczne Sejmu Czteroletniego. Z papierów E. Rabowicza oprac. K. Maksimowicz. Cz. 1: 1788-1789. Warszawa 1998, s. $39,45$. 
cześni, w tym król, który pisał: „Podskarbi Kossowski spełniał zawsze swój urząd uczciwie i na sejmie tym (tj. Sejmie Wielkim - K. M.) wielokrotnie okazał dobre poglądy i zdrowy rozsądek" ${ }^{10}$, jak też badacze czasów stanisławowskich, że powtórzę za Tadeuszem Korzonem: „pracowity i zasłużony w skarbowości” ${ }^{11}$.

Drugą żonę pana podskarbiego, Barbarę z Bielińskich, komplementowano jednogłośnie za urodę. Potwierdzają to mistrzowie zarówno pędzla, jak i pióra. Była kilkakrotnie portretowana. Giovanni Battista Lampi uchwycił jej piękna twarz, klejnot i kwiaty zdobiące ciemne pukle włosów, częściowo zakrywających odsłoniętą pierś, udrapowaną suknię $z$ lekkiego materiału i przezroczysty szal zarzucony na plecy. Równie wspaniale wygląda na portrecie wykonanym przez Wincentego Lesseura, znanego m.in. z misternych miniatur członków wielu rodów magnackich. Nie mniej atrakcyjnie prezentuje się Kossowska na portrecie Józefa Grassiego. Miniaturkę wizerunku na płytce cmentarnej wykonał anonimowy artysta ${ }^{12}$.

Literaci obdarzali małżonkę pana podskarbiego najczęściej epitetami „piękna”, „bardzo piękna”, „cudna piękność”, „ładna jak bożek” itp. Nawet nie darzący jej sympatią autorzy nie odważyli się dołożyć choćby przysłowiowej łyżki dziegciu do jej pięknego wyglądu. Julian Ursyn Niemcewicz zachował ją w swej pamięci jako „najświetniejsza [...] z piękności” czasu Sejmu Wielkiego ${ }^{13}$, a w utworze Co się damom podoba wyznaczył jej miejsce (obok Julii Potockiej i Rozalii z Chodkiewiczów Lubomirskiej) wśród tych, które podbijają świat urodą ${ }^{14}$. Te same trzy damy wskazał Kajetan Koźmian jako „najpiękniejsze kobiety w Warszawie”, a odnosząc się do Barbary Kossowskiej, poszedł jeszcze dalej, uznając ją za „najpiękniejszą z najpiękniejszych kobiet w Warszawie"15.

Na tle wzmianek okazjonalnych dotyczących urody Kossowskiej wyjątkowe

Stanisław August Poniatowski, list do M. Glayre'a, z 25 XI 1789. W zb.: Stanisław Poniatowski i Maurycy Glayre. Korespondencja dotyczaca rozbiorów Polski. Wyd. przez E. Mottaza. Z francuskiego przeł. J. z Chmielowskich Baranowska. Przejrz. i objaśnił T. Krzemińs ki. Cz. 2. Warszawa 1901, s. 99.

11 Korzon, op. cit., t. 4, s. 233. Zob. też A. Berdecka, I. Turna u, Życie codzienne $w$ Warszawie okresu oświecenia. Warszawa 1969, s. 227-228: „Cnota jego stanęła mu na przeszkodzie do fortuny”. - W. Kalin ka, Sejm Czteroletni. T. 2. Warszawa 1991, s. 438: „Kossowski liczył dwadzieścia przeszło lat ministerstwa i urząd swój pełnił sumiennie".

12 Zob. Katalog wystawy sztuki polskiej od roku 1764-1886 z 75 ilustracjami. Wyd. J. B ołoz Ant o ni ewicz. Lwów 1894, s. 51 (nr 273, z informacją: „W. L. 1799. Miniatura owalna, wys. 7 cm., szer. 5,5 cm., wł. hr Tarnowskich w Dzikowie"). - W. B a ch ow ski, M. Treter, Katalog miniatur i sylwetek: wiek XVI-XX. W: Wystawa miniatur i sylwetek we Lwowie 1912. Wyd. 2, uzup. 20 reprodukcjami w druku trójbarwnym i 85 w autotypii. Lwów 1912, s. 137 (nr 610). Zob. też S. Wa sylewski, Portrety pań wytwornych. Warszawa 1924, rozdz. Warszawianka. Edycja współczesna tego wydania: Warszawa 2011.

13 J. U. Niem cewicz, Pamiętniki czasów moich. Oprac., wstęp J. Dih m. T. 1. Warszawa 1957, s. 299.

14 J. U. Ni e m c e wi z z, Dzieła poetyczne wierszem i proza. T. 3. Lipsk 1838, s. 53. W przypisie do miejsca odnoszącego się do wskazanych dam podano: „wszystkie trzy współcześne, pięknością, grzecznym dowcipem i ujmującym obcowaniem równie znakomite; wszystkie w kwiecie młodości zniknęły".

15 K. Koźmian, Pamiętniki. Przedm. A. Kopacz. Wstęp, komentarze J. Willa ume. Wstęp edytorski, ustalenie tekstu w oparciu o autograf oraz komentarz filologiczny M. Ka c z marek, K. Pe cold. T. 2. Wrocław 1972, s. 83; t. 3, s. 196. 
miejsce zajmuje wiersz Kajetana Wierzchowskiego Do... Chociaż adresatka utworu nie została wskazana, ponadto tekst (poza jedną wzmianka) pozbawiony jest realiów, są przesłanki, które pozwalaja ją zidentyfikować. Autor nadmienia też o jej pięknych siostrach.

\section{[...] wdzięków królowa pierwsza $z$ bogów grona, \\ Choć piękności siostrami zawsze otoczona ${ }^{16}$.}

Pomijając hiperboliczny panegiryzm, na jaki wzniósł się poeta, by oddać piękno adresatki, za wskazaniem na Barbarę Kossowską przemawia też inny utwór tego samego autora, Wiersz na dzień urodzin córki J.W. Kossowskiej, podskarbiny koronnej (inc.: „Zosiu, w rocznice twego urodzenia”), w którym obok pochwał i nadziei wiązanej $z$ dziewczynka jest też ukłon w strone jej pięknej matki. $\mathrm{W}$ tym miejscu wypada zadać pytanie: kim był ten bliżej nieznany poeta? Czy skomponował tylko dwa przywołane tu wiersze? Ani Bibliografia polska Estreichera, ani Nowy Korbut (t. 4-6) nie odnotowują jego nazwiska; skrzętnie pomijaja go też świadkowie epoki. Ponieważ autor ten uczestniczył w uroczystości urodzinowej córki podskarbiostwa, to musiał być powiązany z nimi, a przynajmniej z żoną pana podskarbiego. Elżbieta Aleksandrowska wskazała na Pałac Bielińskich, w którym - jak wiadomo - mieszkali Kossowscy, jako ważny ośrodek wielkopański łączący ówczesnych pisarzy ${ }^{17}$. Można więc sądzić, że do grona literatów bywających u Kossowskich należał również ten mniej znany poeta. Marek Jerzy Minakowski wymienia Kajetana Wierzchowskiego herbu Pobóg, urodzonego prawdopodobnie w r. 1770, który w 1800 r. zawarł związek małżeński $z$ Marianną Zofią Worcell herbu Dąb (?) ${ }^{18}$. Zapewne jest to interesujący nas autor.

W Wierszu na dzień urodzin [...] kierowanym do Zosi Kossowskiej poeta zwrócił się też bezpośrednio do jej matki:
Patrz, piękna matko, na twój skarb bogaty,
W którym natura wszystko umieściła;
Ty jesteś wiosna, bo te dałaś kwiaty,
Ty matką wdzięków, boś je utworzyła.

W utworze Do... Wierzchowski ukazał adresatkę jako nieziemskie zjawisko, mające „więcej powietrzną niż ludzką postać”:

\footnotetext{
Jedni brali za nimfę, inni za bóstwo

Lub za tę, która stojąc u Olimpu progów,

Nalewa wonny nektar dla pierwszego $z$ bogów.

O, gdyby on cię ujrzał oczyma swojemi,

$\mathrm{W}$ ten moment byś zapewnie nie była na ziemi.
}

K. Wierzchowski, Do... Bibl. Wojewódzka w Kielcach, rkps 32, s. 143-145. Tekst wskazała i przesłała mi jego fotokopię Pani B ożen a Pias e cka z Działu Zbiorów Zabytkowych i Regionalnych, gdy zwróciłam się z prośbą o udostępnienie mi z tego rękopisu utworu zatytułowanego Wiersz na dzień urodzin córki J.W. Kossowskiej, podskarbiny koronnej, przez Kajetana Wierzchowskiego (w rkpsie na s. 73-74). Za przesłane mi teksty serdecznie dziękuję. Cytowane fragmenty obu utworów pochodzą $\mathrm{z}$ wymienionego rękopisu.

17 E. Al eks a nd row s ka, Geografia środowiska pisarskiego. W zb.: Problemy literatury polskiej okresu oświecenia. Red. Z. Goliń s ki. Seria 2. Wrocław 1977, s. 255.

18 M. J. Min a kow s ki, Genealogia potomków Sejmu Wielkiego. Na stronie: www.sejm-wielki.pl/b/ cz.1024383 (data dostępu: 10 III 2021). 
Autor nie ma wątpliwości, że zazdrosne o jej urodę niebiańskie boginie ogarnęłaby trwoga i doszłoby do kłótni o nią, jak o Helenę trojańską. Olśniewająca urodą adresatka wiersza stapa jednak po ziemi i jest „najdoskonalszą z żyjących istot”, ukształtowana „Ręką Wszechmocnego”. Tak można było pisać o Kossowskiej!

Czy urokowi pięknej Barbary poddał się także Stanisław Kostka Potocki, którego poetycki komplement:

Wszyscy mówią, żeś piękna, jak róża nadobna, Ja mówię, róża piękna, bo tobie podobna

- bywa wiązany z jej nazwiskiem?

Mimo iż tytuł wiersza w rękopisie Biblioteki Śląskiej: Do Pani Kossowski[ej] przez Stanisława Potockiego ${ }^{19}$, wskazywał adresatkę, parający się twórczością literacką Leon Bonawentura Potocki, urzędnik Komisji Krajowej Spraw Wewnętrznych w Warszawie, połączył tenże dystych z metresą króla, Elżbietą Grabowską, a nie z Kossowską. Tym wdzięcznym wierszykiem miano obdarować Grabowską na balu odbywającym się $8 \mathrm{~V} 1780^{20}$. Był to dzień imienin monarchy i jednocześnie święto patrona Polski (św. Stanisława). Przekaz Leona Bonawentury, powstały w oparciu o „żywą tradycję i pamiętniki”, nie do końca jest wiarygodny, na co zwrócił uwagę w przedmowie do wydania zawierającego ten przekaz Stanisław Wasylewski, a zatem nie można wykluczyć, że i w przypadku intrygującego nas wierszyka zaszła pomyłka. Trudno to zweryfikować, gdyż uzyskana od Potockiego informacja nie została opatrzona żadną notą bibliograficzną.

Pochlebstwa na temat urody Kossowskiej wypowiadano chórem, do którego dołączali nawet pamfleciści, wprawdzie uderzający w konduitę damy, ale doceniajacy jej atrakcyjny wygląd. Tak widział ją m.in. autor zagadki sejmowej, który jednak chwalił dość powściagliwie jej urodę: „miła z twarzy, kształtna z nogi”"21.

Piękna pani Barbara zniewalała serca męskie. Zapewne musiało ją łączyć jakieś tajemne uczucie z przywoływanym wcześniej Kajetanem Wierzchowskim, o czym świadczą kierowane do niej w dużej konfidencji jego słowa, mówiące o „znaczących spojrzeniach”, „westchnieniach tajemnych”, wzajemnych „zwierzeniach”, „rozkoszach prawdziwych" itp. ${ }^{22}$ Wyznanie poety wskazuje na dojrzała fazę uniesienia miłosnego, czas „szczerego kochania”, nad który nie może być nic droższego. Nie znamy dalszego ciagu tego uczucia. Nie można też wykluczyć, że w kręgach socjety towarzyskiej był to temat tabu, gdyż chodziło o młodego, początkującego poetę i żonę wpływowego człowieka.

Bibl. Śląska w Katowicach, rkps 171 II, s. 76. Pod tekstem polskim znajduje się przekład na język francuski: „Belle comme une rose, a-t-on dit ce me semble. / Je dis la rose belle, car elle vous ressemble" (cyt. za: E. Al e k s a n d r o w s ka, Objaśnienia. W: Poezje zebrane Wojciecha Miera. Zebrał i oprac. E. Rabowicz. Uzup. i przygot. do druku E. Aleksandrowska. Wrocław 1991, s. 323).

20 L. B. Po t o c ki, Bal królewski $w$ dniu św. Stanisława. W zb.: Przypadki króla Jegomości. Opowieści ludzi wspótczesnych. Zebrał, przedm. S. W a s ylew s ki. Kraków 1957, s. 36.

21 Zagadki Sejmu Czteroletniego. Teksty zebrał i ustalił E. Ra b ow i c z. Komentarze oprac. B. Krakowski, E. Rabowicz. Do druku przygot. J. Kow e cki, Warszawa 1996, s. 189. Zob. P. Kac zy ń s ki, Życie seksualne jako obiekt krytyki i źródło inwektyw $w$ literaturze politycznej czasów stanisławowskich. Casus „Zagadek Sejmu Czteroletniego”. „Prace Polonistyczne” 2013, s. 94.

Wierzchowski, Do... 
W biografię Kossowskiej wpisana była plotka salonowa do tego stopnia, że (chwilowy) jej brak aż budził zdziwienie. Bez tego typu doniesień Warszawa wydawała się wręcz nieatrakcyjna. To, że „Pani Kosso[w]ska żadnych rewolucji w państwie miłostek nie zrobiła", uznał Wojciech Mier za nieprawdopodobne ${ }^{23}$.

Konduita Kossowskiej dodawała smaczku salonowemu życiu w stolicy. Atrakcyjna pod wieloma względami kobieta doskonale współtworzyła ówczesny model życia pań $z$ wyższych sfer czasów stanisławowskich. Chociaż Roman Kaleta pominą ją w rozprawie na temat „oświecenia swawolnego” 24 , to z powodzeniem mogłaby tam się znaleźć. Wchodząca w związek pozamałżeński (z jakiegokolwiek powodu) dama nie należała do wyjątków. W kontekście tej konstatacji wypada zapytać: czy romans Barbary Kossowskiej z Gustawem Stackelbergiem, synem ambasadora, miał posmak polityczny? Opowieść życzliwego Polsce dyplomaty, hrabiego Larsa Engelströma, zdaje się wskazywać, że cała sytuacja związana z tym romansem nie była pozbawiona kontekstu politycznego. Opowiadając o obiedzie u księżnej Sanguszkowej, Engelström przekazał ciekawostkę, związaną też z przebywającym w Warszawie w czasie Sejmu Wielkiego posłem angielskim Danielem Johnem Hailesem:

Hailes był zakochany w bardzo pięknej pani Kossowskiej ( $z$ domu Bielińskiej, urodzonej z Sanguszkowej, żonie Rocha Kossowskiego, podskarbiego koronnego), a pani tej zdawał się więcej przypadać do smaku Gustaw Stackelberg, syn ambasadora. Hailesowi zdawało się, iż przez odwołanie ojca i jego się pozbędzie. Tak to się dzieje na świecie! ${ }^{25}$.

Hailes miał powody ku temu, by pozbyć się z Polski ambasadora rosyjskiego; zapewne ze względu na osobiste zaangażowanie w sprawę aliansu polsko-pruskiego, a być może także $z$ chęci uwolnienia się od niechcianego konkurenta do serca Kossowskiej. Faktem jest, że ojciec młodego Stackelberga został odwołany z Warszawy w połowie 1790 roku. Nie przyniosło to jednak pożądanego przez Anglika rezultatu, gdyż dama nie odwzajemniała jego uczuć. Można podejrzewać, że nieatrakcyjny wygląd dyplomaty - był „rudy, brzydki i nieznośny” 26 - nie skłonił do niego serca pięknej kobiety, która miała być przeświadczona, że za sprawą odwołania Stackelberga stał ten jej wielbiciel.

Czy Barbara Kossowska kokietowała Kazimierza Nestora Sapiehę, jak podał Wasylewski ${ }^{27}$, nie wiemy, aczkolwiek wydaje się to prawdopodobne. Sapieha słyną $\mathrm{z}$ bogatego życia towarzyskiego, by nie powiedzieć: erotycznego, poza tym w czasie Sejmu Wielkiego przeszedł metamorfozę i stał się ważną postacią w stronnictwie

W. M i e r, List [III] do Pana Stanisława Potockiego. W: Poezje zebrane Wojciecha Miera, s. 138 (utwór nosi datę dzienna: 23 10-bre; domniemany rok powstania: 1783). Zob. też wcześniejsze wydanie tego wiersza, pt. [Do Stanisława Kostki Potockiego]: R. Kal et a, Przyjaciele i zalotnicy. Korespondencja poetycka i wiersze do Krajczyny Potockiej, Wojciecha Miera, Stanisława Potockiego i Wojciecha Turskiego. W zb.: Miscellanea z doby oświecenia. [T.] 3. Wrocław 1969, s. 301-302. R. Ka l e ta, Oświecenie swawolne $w$ świetle nieznanej satyry bibliograficznej. W: Oświeceni i sentymentalni. Studia nad literatura i życiem $w$ Polsce $w$ okresie trzech rozbiorów. Wrocław 1971. L. En ge st r ö m, Pamiętniki. W zb.: Polska stanisławowska w oczach cudzoziemców. Oprac., wstęp W. Zawadzki. T. 2. Warszawa 1963, s. 169. Zob. Korzo n, op. cit., t. 4, s. 238. 
patriotycznym, a pani Kossowska manifestowała wówczas swój patriotyzm. Ta sama orientacja polityczna mogła ich zbliżyć do siebie.

Z cała pewnością obiektem zainteresowania Kossowskiej stał się książę Józef Poniatowski, będacy „celem westchnień wszystkich kobiet” w stolicy, jak ujął to Koźmian, opisując zabawne zdarzenie $z$ udziałem trzech warszawskich piękności (jedną z nich była Kossowska). Zabiegające o względy bratanka Stanisława Augusta damy - pisał Koźmian - postanowiły sprawić mu niespodziankę i w dniu jego święta:

zebrały się raz Pod Blachą, przekupiły kamerdynera, że ich wpuścił w niebytności księcia do pokoju sypialnego księcia i tam kwiatami łóżko jego wieńczyły, gdy książę niespodzianie najechał z swoją faworyta, aktorką Sitańską, i wszedł do pokoju. Spotkanie to nie bardzo było z obóch stron przyjemne28.

Ścigające Kossowska plotki oraz anegdotki salonowe przekazywane były $z$ ust do ust $\mathrm{i}$ - jak zdarza się w takich sytuacjach - mogły ulegać zmianom czy zniekształceniom. Trudno uwierzyć w „pikantną" relację pamiętnikarską rzekomego Bartłomieja Michałowskiego ${ }^{29}$, odnoszacą się do „bohaterki” niniejszego studium, chociaż, z drugiej strony, wizerunek swawolnej Kossowskiej rozpowszechniany był przez pamflecistów. Jak można podejrzewać, zapewne ze względu na prestiż rodziny Barbara Kossowska - „kobieta rzadkiej urody, ale rozwiąła, a mająca zachowanie u dworu” - występuje w Pamiętniku pod inicjałami „K. P. K.” W opowieści pana Bartłomieja zastawiła ona miłosne sidła na Johna Howarda, angielskiego reformatora więziennictwa. Wizualnie nie był to atrakcyjny mężczyzna: „niewielkiego wzrostu, chudy, z dużym nosem, małomówny i zimny jak po większej części jego rodacy". Podobno nie miał w sobie nic pociagającego, ale jego szlachetna postawa („czystość obyczajów”) zjednywała mu sympatię ${ }^{30}$. Poza tym nie sposób nie zauważyć, że przybysz z Anglii miał już za sobą młodość; przeżył ponad 50 lat. Dla pani Kossowskiej wiek Howarda chyba nie miał większego znaczenia (od swego małżonka była ona młodsza o ćwierćwiecze). Co zatem sprawiło, że upodobała sobie Howarda? Być może, jego niedostępność, hołdowanie surowości obyczaju, albo - jak nazwał to autor opowieści - po prostu kaprys damy. Rzekomy pan Bartłomiej Michałowski ujawnił, iż uczucie Kossowskiej do Howarda nabrało cech "gwałtownej miłości” do tego stopnia, że "na koniec tak otwarcie i natarczywie się do niego wzięła będąc z nim sam na sam, że przecie poznał, czego chce od niego". A ponieważ Anglik nie uległ jej, stało się to prawdziwą sensacją. Barbara Kossowska „pierwszy raz w życiu ujrzała swe wdzięki wzgardzone", a w salonach warszawskich i na dworze królewskim „długo żartowano z jej niepowodzenia”31. Wcielając się w postać Putyfarowej żony, Kossowska poniosła fiasko ${ }^{32}$.

Zapewne istnieje jakieś źdźbło prawdy w tej historyjce. Echo takich wydarzeń $z$ Kossowską w roli głównej słyszalne jest w pamfletach. Jeden $z$ autorów, w którym Kaleta domniemywał Adama Naruszewicza, użalał się nad Rochem Kossowskim, uznając, że pożycie z niewierną małżonką stanowi prawdziwą katorgę:

Koźmia n, op. cit., t. 2, s. 83.

[H. Rzew u ski], Pamiętniki Bartłomieja Michałowskiego od roku 1786 do 1815 ogłoszone przez Henryka hr. Rzewuskiego. T. 1. Warszawa 1857, s. 101.

Ibidem, s. 102.

Ibidem.

Zob. ibidem, s. 103. 


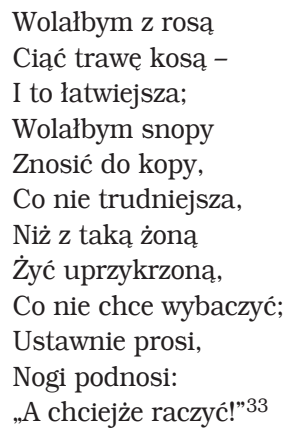

Inni satyrycy szydzili z męża damy - rogacza. Nieznany autor zagadki sejmowej obwieszczał publiczne:

W skarbie siedzi i senacie,

Radby o większej zapłacie,

Żonę ma ładną jak bożek,

Przydomek mu dają Rożek ${ }^{34}$.

Niektórzy pamfleciści szli jeszcze dalej i z rożka czynili rogacza. Awansując Kossowskiego na typowego rogacza, „dowartościowywali” go:
Słyszałem, gdy cię Rożkiem damy zwały, Jam się też ciebie tak nazwać odważył. Mówisz, że jestem nazbyt poufały.
Prawda, źlem bardzo tego słowa zażył.
Niech twoja godność tego nie przebacza
Jak to zaś Rożkiem nazywać Rogacza ${ }^{35}$.

Niewiele wiemy o tym, jaka była reakcja (bo faktycznie jej nie znamy) pana podskarbiego na kompromitujące go i jego małżonkę wierszyki. Prawdopodobnie nikła; tak też można sądzić na podstawie anonimowego głosu rymopisa, odnoszącego się, co prawda, do niewiernej żony pana Rocha, ale w sposób pośredni także do niego, jakkolwiek byśmy to interpretowali:

Umizga się jak panna.
Męża ma swego jak żaka,
Zrobiła z niego ślimaka ${ }^{36}$.

R. Ka le ta, Antologia poetycka Franciszka Ksawerego Woyny. „Ze Skarbca Kultury” 1983, z. 38, s. 82. - L. S a cullu s [R. Ka le ta], Poezyje desertowe wieku naszego oświeconego, Amsterdam 1789 [Wrocław 2019], s. 132.

J. N ow a k [- Dł uż e w s ki], Satyra polityczna Sejmu Czteroletniego. Kraków 1933, s. 131, 213. Ka le t a, Antologia poetycka Franciszka Ksawerego Woyny, loc. cit. - Zagadki Sejmu Czteroletniego,

s. 67-68. - Ka czyńs ki, op. cit., s. 86. - Sa cullu s, op. cit., s. 388.

Tej samej kwestii dotyczą też następujące zagadki (Zagadki Sejmu Czteroletniego, s. 189, 179):

1) Rożkiem go zowią, a on rogacz cały. Dwie ładne żony cnota go przybrały, Chociaż poczciwy, mało ma przyjaźni Bo często swym brutalstwem drażni.
2) Miła z twarzy, kształtna $z$ nogi, Prześlicznie zaszczepia rogi. Kto by miał mówić, że to powieść płocha, Niech spojrzy na głowę Rocha. 
Niewątpliwie było to czytelne nawiązanie do "rogów” (jednej lub dwóch par czułków) ślimaka, ale też mógł być inny wydźwięk znaczenia frazy: „Zrobiła z niego ślimaka”, czyli zamknął się jak ślimak w skorupie i nie interesował się złośliwymi wierszykami.

Wydaje się, że Kossowski nie zasługiwał na takie upokorzenie. Przypisywano mu nawet utwór Rada dla wszystkich młode żony majacych ${ }^{37}$. Drugim pretendentem do firmowania tego tekstu był Piotr Ożarowski, którego nazwisko widniało w Katalogu ksiag znajdujacych się w Księgarni Grelowskiej w czasie kontraktów $w$ Dubnie roku $1784^{38}$. Niezależnie od tego, czyim nazwiskiem opatrywano utwór, intencje były czytelne. Obaj mężowie mieli dane ku temu, by trafić do satyry obyczajowej. Małżonka Ożarowskiego, Marianna z Dzierzbickich, utrzymywała wieloletni związek pozamałżeński z Ottonem Stackelbergiem ${ }^{39}$.

Nie potrafimy powiedzieć, spod czyich piór wychodziły pamflety na Barbarę Kossowską i jej męża, w związku z czym ograniczymy się do domniemania Aleksandrowskiej, że podejrzewano o nie Franciszka Zabłockiego i Franciszka Ksawerego Dmochowskiego 40 .

Pamflety krążły, a piękna pani Kossowska nie ustawała w romansach. Na liście zdobywców jej serca znalazł się także „nad miarę zalotny” Tadeusz Mostowski, do którego wzdychały najpiękniejsze damy w Warszawie ${ }^{41}$. Był to ostatni adorator Kossowskiej, mający zresztą (mimo dobrych intencji) związek z jej śmiercią; będzie o nim mowa dalej.

Tak jak podbijanie serc męskich zaprzątało Kossowską, tak też udział w różnego rodzaju imprezach stanowił ważną część jej życia. Preferowała bale.

Zamiłowanie do tego typu rozrywki wyniosła $z$ domu babki Sanguszkowej. Leon Bonawentura Potocki podał interesujący szczegół odnoszący się do „pięknej i młodej Kossowskiej”, która podczas jednego z balów wcieliła się w postać staroitalskiej Diany. Przebrana za boginię prezentowała się „w rogówce $\mathrm{z}$ upudrowaną fryzurą, wśród której półksiężyce, wysadzone brylantami”, co relacjonujący opatrzył żartobliwym komentarzem: „Szkoda, że dziwnego stroju Diana nie prowadziła na różowej wstażce białego bonońskiego pieska, zamiast charta, jak nam ją w mitologii malują"22.

Pomijając temat sposobu przedstawiania bogini (m.in. ubrana w długą haftowana szatę, wyposażona $\mathrm{w}$ atrybuty ze świata zwierzą, w tym towarzysząca jej sforę psów), kreacja pani Kossowskiej miała niewiele wspólnego z Dianą; nie była na miare przekazu mitologicznego. Piękna Barbara musiała jednak zrobić duże wrażenie, gdyż jej oryginalne wcielenie w mitologiczna postać na długo pozostało w pamięci nie tylko świadków zdarzenia. Przypomniano o tym w czasie wielkiego obradowania: „Kobieta niby Dyjanna” 43 .

Wileńska Bibl. Akademii Nauk, rkps Fond 147-148, k. 91: Rada dla wszystkich młode żony majacych, $w$ Warszawie, przez Kossowskiego.

Katalog ogłosił R. Kaleta w Aneksie do rozprawy Oświecenie swawolne [...], s. 317-320; na s. 318: Rada dla wszystkich młode żony mających, przez Ożaro[w]skiego (z rkpsu Bibl. Ossolineum, 1074, k. 108-109).

Zob. Kaczyńs ki, op. cit., s. 80.

Aleks a ndrows ka, op. cit., s. 323.

Koźmian, op. cit., t. 3, s. 229.

P o t o c ki, op. cit., s. 34 .

Zagadki Sejmu Czteroletniego, s. 168. 
Przyjmujac za wiarygodny opis Kossowskiej-Diany pióra Leona Bonawentury Potockiego, nie sposób nie zauważyć nieścisłości wynikającej z chronologii zdarzeń. Uczestnicząca w 1780 r. w balu pani Kossowska - tego nazwiska używa autor - nie była w tym czasie mężatką, a więc nosiła nazwisko panieńskie: Bielińska.

Czy w rezydencji Kossowskich odbywały się bale na miarę opisanego przez Potockiego, chyba można odpowiedzieć twierdząco. Wiemy, że z okazji imienin Rocha Kossowskiego jego żona urządzała trzydniowe imprezy towarzyskie, na których bywał Stanisław August, a w razie nieobecności monarchy pojawiał się w Pałacu Bielińskich goniec królewski z powinszowaniem dla solenizanta. Gości przyjmowano $\mathrm{z}$ atencja, Kossowski okazywał im serdeczność, a pani domu błyszczała salonową uprzejmością ${ }^{44}$.

Z atmosfery balu i zauroczenia tańczącą Barbarą Kossowską wyrasta utwór Do Kossowskiej $w$ tańcu, którego atrybucja autorska do dzisiaj pozostaje sprawą otwartą. W rozważaniach dotyczących tej kwestii jako poważny pretendent do autorstwa wskazywany jest Stanisław Trembecki, ale też wymienia się Adama Naruszewicza czy Józefa Szymanowskiego. Ten skomplikowany problem filologiczny zaprzątał badacza twórczości Trembeckiego, Wojciecha Kaliszewskiego, na sympozjum warszawskim w okragła, 200 rocznicę śmierci poety ${ }^{45}$. Zagadkowy jest też czas powstania utworu. Wiadomo tylko, że wiersz zainspirowany był tańcem Kossowskiej na publicznej zabawie maskaradowej, a tego typu bale odbywały się przed adwentem oraz podczas karnawału.

Magii tańczącej damy „na warszawskiej reducie” poddał się zarówno twórca wiersza, jak też świadkowie tego wydarzenia, bo czy może być coś piękniejszego od widoku „podskakującego w tańcu bóstwa”?

\author{
Śliczna w postaci, żywa jak łania, \\ Oczki jak zorza, usta w rubinie, \\ $Z$ rączym się wiatrem w tańcu ugania, \\ Chwyta za serce, kto się nawinie. \\ Nóżki się ledwie widzieć pozwolą \\ I czasem tylko dotkną się ziemi, \\ Wszystkie w niej członki razem swawolą, \\ I zefir igra $z$ gazy wietkiemi ${ }^{46}$.
}

Był to opis $z$ autopsji, $z$ nutą erotyczną. Unoszący lekko do góry spódniczkę i fartuszek tancerki zefirek jest w lepszej sytuacji niż poeta, gdyż muska usta i wi-

Zob. E. Heleniu s z [właśc. E. I w a n ow s ki], Pamiątki polskie z różnych czasów. T. 2. Kraków 1882, s. 387.

45 Sprawę autorstwa wiersza przedstawił W. Kal is zew s ki 12 XII 2012 na konferencji $W$ dwusetną rocznicę śmierci Stanisława Trembeckiego w Instytucie Badań Literackich w Warszawie w ramach prac Zespołu Europeistyki Literackiej (organizatorzy: J. Snopek i W. Kaliszewski). Jego studium „Śliczna w postaci, żywa jak tania”. Kwestia autorstwa wiersza znanego pod tytutem „Wiersz na pochwate J.W. Kossowskiej, podskarbiny nadwornej koronnej z okoliczności jej tańca na warszawskiej reducie" dotąd nie ukazało się drukiem. Zdaniem referenta, autor wiersza nie został do tej pory rozpoznany. Kaliszewski przypuszcza, że mógł to być J. Szymanowski, ale ta hipoteza - jak twierdzi - wymaga jeszcze kolejnych (poza przedłożonymi w referacie) dowodów. W tej sytuacji konkluduje badacz - wiersz nie powinien znajdować się w kanonie utworów Trembeckiego. Jego miejsce jest $\mathrm{w}$ dziale dubiów. 
dzi jej „najtajemniejsze skrytości”. Cała postać tańczącej („wszystkie w niej członki”) jest wabiąca, a szczególnej ekscytacji erotycznej dostarczają „ledwie widoczne nóżki”. Tancerka jest nieuchwytna, eteryczna, niemal unosi się nad ziemią. Jej wygląd i mistrzostwo, jakie osiągnęła w sztuce tańca, tworza „czarowny widok [...] chwytający za serce”, nęcący bożka miłości. Jest tak doskonała w tańcu, że wdziękiem przewyższa gracje olimpijskie:

\author{
Daremna chluba, gracyje, wasza, \\ Że Olimp swymi pląsy dziwicie, \\ To tu na ziemi Kossowska nasza \\ Umie śmiertelnych zabawić życie ${ }^{47}$.
}

Widok pięknej Kossowskiej w tańcu jest godny upamiętnienia przez najlepszych artystów, poetów i malarzy, mimo iż może grozić im niebezpieczeństwo w postaci „losu Pigmalijona”. Maria Grzędzielska ustaliła, że wirująca „na warszawskiej reducie” tancerka prezentowała się w menuecie, w którym „podskok przypada co trzeci krok w takcie". Taniec ten cieszył się duża popularnością w czasach Ludwika XIV. Inne zdanie w tej sprawie miał Wasylewski, nie tylko podający nazwę tańca, ale także wskazujący partnera tancerki. Wydaje się, że wyobraźnia Wasylewskiego poszła zbyt daleko. Na poczatku widział Kossowską w walczyku w parze z młodym Stackelbergiem, a po zmianie partnera, którym został książę Pepi - w kozaku ${ }^{48}$.

Inne wydarzenie, jakim było wystawienie przez Kossowską w okresie wielkiego sejmowania na początku r. 1791 inscenizacji obrazującej cztery pory roku, zainspirowało Wojciecha Miera do napisania panegiryku - jak można podejrzewać, ku uciesze animatorki spektaklu, a zapewne i dla rozweselenia oglądającego go towarzystwa. Mier, bywalec warszawskich salonów, skomponował swój utwór „na gorąco", następnego dnia po owym wydarzeniu. Mając świeżo w pamięci przeżycia, jakich doznał oglądając piękną Kossowską w lekkiej scence rodzajowej, bezceremonialnie manifestował swą chęć pozyskania jej serca. Wyznanie poety ma posmak frywolny. Z każdą porą roku żądza zdobycia adresatki potęgowała się: Wiosna - „nad dzień milsze” byłyby z nią noce; Lato - stałby się rozpalonym upałem; Jesień - nie zważając na karę, gotów byłby sięgnąć po „owoc zakazany”; Zima zaś mogłaby się okazać dla niego niebezpieczniejsza od upalnego Lata ${ }^{49}$.

Wpisana w atmosfere zabawy biografia Barbary Kossowskiej zmienia się pod wpływem ważnych wydarzeń krajowych. Dama rokokowa przeistacza się w patriotkę. W pierwszą rocznicę uchwalenia Konstytucji 3 Maja była obecna na premierze Kazimierza Wielkiego Niemcewicza ${ }^{50}$, sztuce powstałej na zamówienie Stanisława Augusta, której akcja, choć o tematyce historycznej, odnosiła się do okresu współ-

Ibidem, s. 80.

M. Grzędzi els ka, Wiersz - taniec. „Roczniki Humanistyczne” t. 46 (1998), z. 1 (zeszyt specjalny), s. 85. - W a sylew s ki, op. cit., s. 70.

W. M i e r, Do K... [Kossowskiej] wystawiajacej kolejno cztery pory roku (wyd. E. Al e k s a n d r o ws ka). W: Poezje zebrane Wojciecha Miera, s. 110-111 (według: „Tygodnik Polski i Zagraniczny” 1818, t. 4, s. 223-224; zob. też „Świat poprawiać-zuchwałe rzemiosło”. Antologia poezji polskiego oświecenia. Oprac. T. Kostkiewiczowa, Z. Goliński. Warszawa 1981, s. 232 (według: „Poezja” 1966, nr 10 (wyd. R. Kaleta〉).

Zob. W. Zaw a d z ki, Teatr we wspomnieniach i listach. W zb.: Teatr Narodowy 1765-1794. Red. J. Kott. Oprac. J. J a ck1 [i in.]. Warszawa 1967, s. 668-669. 
czesnego autorowi. Barbara Kossowska, tak jak inne damy przybyłe na przedstawienie, akcentowała swą postawę patriotyczną poprzez strój w barwach narodowych, biało-pąsowych, znajdujących się w tle herbu Korony i Wielkiego Księstwa Litewskiego. Gdy podczas trwania spektaklu król wypowiedział słowa: „Stanę i wystawię się", odnoszące się do sytuacji zagrożenia niepodległości kraju, Kossowska razem z innymi oklaskiwała monarchę i wiwatowała na jego cześć. Nie sposób wyobrazić sobie, by nie poddała się atmosferze panującej na sali.

Trochę wcześniej, w aurze entuzjazmu pokonstytucyjnego, pani Barbara obnosiła się ze swym patriotyzmem poprzez wyrażanie niechęci do przybyłego do Warszawy we wrześniu 1790 Jakowa Bułhakowa, który, co prawda, w porównaniu z odwołanym swym poprzednikiem prezentował się lepiej, to jednak jego działalność była groźniejsza dla Polski niż działania Stackelberga. Okazji do wystapień przeciwko Bułhakowowi dostarczyła jego loża teatralna, która po odnowieniu Teatru Narodowego dorównywała wytwornością loży królewskiej. Solą w oku Kossowskiej stało się już samo usytuowanie loży ambasadora, zbyt blisko jej loży. Jak informowały nowinki gazeciarskie, Kossowska nie żałowała pieniędzy, by manifestować swą wrogość do niego ${ }^{51}$.

Powszechnie znane były w stolicy jej zatargi z kolejnym ambasadorem, Jakowem Sieversem (mianowanym 12 XII 1792). Wypada jednak zapytać, jak zachowywała się, kiedy jej stryj, Stanisław Kostka Bieliński, marszałek sejmu grodzieńskiego, fetował - dając wspaniałą iluminację - przypadające na dzień 25 VII 1793, a obchodzone przez tydzień imieniny ambasadora, mąż zaś wszedł z polecenia Sieversa do restytuowanej Rady Nieustającej (21 IV 1793), w związku z czym (mimo przystapienia do powstania i sprzyjania insurekcji) nie budził zaufania władz powstańczych. W tym samym czasie ojciec Kossowskiej, uczestnik powstania kościuszkowskiego, dawał przykłady patriotyzmu ${ }^{52}$ (m.in. przekazał „na potrzeby publiczne plon ze swych dóbr otwockich, gdy stolicy i armii groził głód"53). I w tym miejscu stajemy przed problemem: czy - jak pisał Wasylewski - Kossowska nie zdobyła się na to, by wspierać insurekcję, angażując się w prace na okopach, wzorem wielu ówczesnych kobiet, czy może - co akcentował Wacław Tokarz - była "gorliwa patriotka" ${ }^{4}$. Prasa donosiła o dzielnych niewiastach "najznakomitszego nawet urodzenia”, które „pod przewodnictwem obranej między sobą dowódczyni, siedzącej na koniu z pałaszem, wychodziły wśrzód muzyki codziennie do okopów, pracując $z$ bezprzykładna gorliwościa w tym chwalebnym ogólnej obrony dziele", ale wśród nich nie było Kossowskiej ${ }^{55}$. Czy okazała się ona posłuszna wezwaniu Tadeusza Kościusz-

Zob. J. J a c k 1, Teatr i życie teatralne w gazetach i gazetkach pisanych (1763-1794). W zb.: Teatr Narodowy 1765-179, s. 595-596 (Loża ministra rosyjskiego z innymi zrównana. „Z Warszawy, die 7 7-bris 1791").

52 Zob. Wiersz na iluminacja dawana przez Bielińskiego, marszałka sejmu 1793 roku w Grodnie, na imieniny Sywersa, posła moskiewskiego oraz O tymże inaczej. W zb.: Wiersze polityczne czasu konfederacji targowickiej i sejmu grodzieńskiego 1793 roku. Oprac. K. Ma k s i mow ic z, Gdańsk 2008, s. 394-396. - Krakow s ki, op. cit., s. 318. 
ki Do kobiet polskich, dotyczacemu przygotowywania przez kobiety szarpi i bandaży dla wojska? ${ }^{56} Z$ drugiej jednak strony, nie można wykluczyć, że na decyzję (z 25 III 1794) oberkwatermistrza rosyjskiego, majora Titowa, w sprawie zakwaterowania w warszawskim Pałacu Kossowskich 100 grenadierów, mogła (choćby w jakiejś mierze) wpłynąc postawa patriotyczna Kossowskiej ${ }^{57}$.

Wcielając się w rolę patriotki, nawet w romansach kierowała się koneksjami politycznymi. Pomijając Kazimierza Nestora Sapiehę, o którym już tu wspomniano, zdobyła serce kasztelana raciąskiego, dyplomaty i działacza politycznego, Tadeusza Mostowskiego. Odsłaniający kulisy tego związku Koźmian ukazał go jako połączonego „duchem i sercem $z$ najcelniejszymi patriotami”, a jednocześnie jako dość bezceremonialnego amanta wychowanego we Francji. Pisał o nim: „piękny, urodziwy, dowcipny i nader zalotny a psuty od kobiet [...], znający słabości kobiet i z uwodzenia czyniący sobie igraszkę, przy tym sceptyk i wolterowskiego wieku pojętny uczeń"58.

$Z$ romansem tym wiąże się jednak smutna historia, znana z opowieści Koźmiana:

Młoda Kossowska zachorowała na szkarlatynę, [a] że [Mostowski - K. M.] sam doktorów nienawidził i sam się zwykł był leczyć - ze wszystkich systemów lekarskich przychylny panującemu wtedy systemowi Brauna - poradził jej użycie starego wina; dostała zapalenia gardła i umarła ${ }^{59}$.

Tak więc, idąc za radą Mostowskiego, Kossowska poddała się leczeniu niekonwencjonalnemu, jakie propagował nieżyjący już wówczas medyk szkocki, John Brown (zm. 1788). Zgodnie z zaleceniami Browna, kurację miały wspomagać podniety takie, jak alkohol (wino) czy przyprawy korzenne ${ }^{60}$. Śmierć młodej i pięknej kobiety, do tego poddanej kontrowersyjnej metodzie leczenia, nie przeszła bez echa. Odium społeczne spadło na Mostowskiego, a największą siłą ataku wykazali się bracia zmarłej, Paweł i Józef Bielińscy. Nawiasem mówiąc, obaj „nienawidzący” związku siostry $\mathrm{z}$ Mostowskim ${ }^{61}$.

Barbara Kossowska niemal do końca swych dni uczestniczyła w życiu towarzyskim. W roku śmierci wystapiła w rezydencji Małachowskich w pantomimie Psyche. Poszukując uśpionego Erosa, trzymała kaganiec w dłoni; grała zachwycająco ${ }^{62}$.

Śmierć Kossowskiej uczczono dwoma epigramatami funeralnymi. Jeden z nich umieszczono na jej grobie na nieistniejącym dziś cmentarzu świętokrzyskim „na Koszykach" w Warszawie:

\footnotetext{
Tu leży Barbara z Bielińskich Kossowska, umarła d[nia] 10 czerwca 1801 roku. Cnotliwej matki zwłoki ta kryje mogiła, Dzieciom życie ratując, swoje utraciła ${ }^{63}$.
}

ty sesji „Tadeusz Kościuszko. Historia - mity-tradycja”. Szczekociny, 6-7 czerwca 2014 roku. Red. M. Trą bs ki. Warszawa 2016, s. 139. - W a sylewski, op. cit., s. 75-76.

Zob. Maksimowicz, op. cit., s. 138.

Zob. Tokarz, op. cit., s. 214.

Ko żmia n, op. cit., t. 3, s. 194-196.

Ibidem, s. 196.

Zob. B. Pło n k a - Sy r o k a, Doktryna Johna Browna (1736-1788), jej geneza i recepcja $w$ medycynie europejskiej $w$ kontekście kształtowania się standardu klinicznego. Cz. 1. „Medycyna Nowożytna. Studia nad Kulturą Medyczną" t. 24 (2018), z. 1, s. 23-24.

Zob. Koźmian, op. cit., t. 3, s. 196.

Zob. W a sy lew ski, op. cit., s. 76 .

A. K o s s e c ki, Nagrobki XVIII stulecia na byłym cmentarzu Św. Barbary na Koszykach w Warsza- 
Enigmatycznie brzmiące słowa w ostatnim wersie nagrobka nie znajdują potwierdzenia w biografii zmarłej. Mimo iż wiele faktów $z$ jej życia, w tym nie zawsze istotnych, znajdujemy w różnego typu przekazach, to sprawa śmierci - poza informacją odnotowana przez Koźmiana i zawartą w cytowanej inskrypcji nagrobnej owiana jest tajemnica. Czyżby chodziło o jakieś wydarzenie tragiczne, matczyne poświęcenie? Zmarła zostawiła niepełnoletnie swe dzieci: dwie córki i dwóch synów. Najstarsza córka miała 11 lat, a najmłodsze dziecko liczyło lat 6. Fetowana wierszem urodzinowym autorstwa Kajetana Wierzchowskiego Zofia wyjdzie za mąż za Ignacego Wielopolskiego, Krystyna poślubi Adama Świejkowskiego, Karol Franciszek Antoni zostanie oficerem wojsk polskich, a Maurycy Tadeusz będzie w latach 18231833 dyrektorem kancelarii w Komisji Rządowej Spraw Wewnętrznych i Policji64.

Rękopis drugiego epitafium, zatytułowanego Na śmierć Barbary Kossowski (!), znajduje się w Bibliotece Książąt Czartoryskich w Krakowie:

\title{
Wdzięki, których zawiści czasu dotknąć bronił, Twórca ich snu spokojną powłoką zasłonił, A zwykle przez powaby drażnioną zwodnicze, Powrócił czułą duszę przed swoje oblicze ${ }^{65}$.
}

Autor tego wiersza nagrobnego musiał być pod urokiem pięknej kobiety i nie tylko jej ciała, ale też duszy. Oba epitafia można by umieścić w dziale szlachetnej twórczości okolicznościowej.

Osoba tak niepospolita jak Barbara Kossowska zasługuje na to, by wizerunek jej nie został zapomniany, a personalia jej nie trafiły tylko do przypisów w dziełach historycznych ${ }^{66}$.

\author{
Abstract \\ KRYSTYNA MAKSIMOWICZ The State University of Applied Sciences in Elblag \\ ORCID: 0000-0001-7545-9228
}

\section{A LITERARY IMAGE OF BARBARA KOSSOWSKA, NÉE BIELIŃSKA}

The article attempts to picture a literary image of Barbara Kossowska, née Bielińska, a lady of the times of Stanisław August Poniatowski, famous for her beauty. The heroine of the study was largely recalled as an addressee of the poem Do Kossowskiej $w$ tańcu (To Kossowska in Her Dance) that raised researchers' interest mainly due to the author's attribution. Regardless of it, she was referred to because of her husband, Roch Kossowski, a grand royal undertreasurer. The authoress of the article depicts the many incarnations of Barbara Kossowska shaped by panegyrists and lampoon writers.

wie. Krasnystaw 1924. Zob. też. K. W. Wó j c i c ki, Cmentarz Powazkowski pod Warszawa. T. 3. Warszawa 1958. Także na stronie: Cmentarium.sowa.website.pl/Epitafia/Warszawa swietokrzyski. htlm (data dostępu: 10 III 2021). - Kr a kow s ki, op. cit., s. 318.

Zob. Krak ow ski, op. cit., s. 318.

Bibl. Czartoryskich, rkps 6119 III, s. 187. Aktualną sygnaturę ustaliła Pani Kustosz D or o ta O twi nowska, przekazując mi jednocześnie odpis wiersza nagrobnego, za co składam Jej podziękowanie, a także dziękuję pośredniczącemu w tej sprawie Panu Piotrowi Nowakowi z Sekcji Ruchu Muzealiów i Kwerend Naukowych.

Zob. S. F u ks i ew i c z, Kossowski Maurycy Tadeusz. Hasło w: Polski słownik biograficzny, t. 14, s. 315 . 